\title{
Plant maintenance management practices in automobile industries: A retrospective and literature review
}

\author{
Mahesh Pophaley ${ }^{1}$, Ram Krishna Vyas ${ }^{2}$ \\ ${ }^{1}$ Medi-Caps Institute of Technology and Management (INDIA); ${ }^{2}$ International Institute of Professional \\ Studies, Devi Abilya University (INDIA) \\ mahesh_pophaley@rediffmail.com; ramkrishnavyas@yahoo.com
}

Received October 2009

Accepted June 2010

\begin{abstract}
This paper endeavors to present a classification, review and analysis of the literature on Plant Maintenance Management Practices (PMMP) employed in Automobile Industries. There is a considerable amount of published research available concerning plant maintenance during the last few decades. Similarly many research articles are available which focuses on various aspects of automobile industries. However, very few studies focus on critical examination of maintenance practices in Automobile Industries in particular. Hence considering the slump in automobile industries in the recent times, a wide-ranging and focused review is attempted here and only those researches have been examined which mainly concentrates on this core aspect. Thus one of the objectives of this literature review is to investigate the present state of Plant Maintenance Management Practices, based on studies conducted in different countries and published in a variety of journals over the past two decades. An examination of 55 pertinent research studies have shown that the publications can be grouped in two categories namely Conceptual and Empirical Research. An analysis of these research articles published between 1990 and 2008 , revealed that current maintenance practices ranges from conventional to the latest techniques for optimizing maintenance function like TPM, RCM and Proactive Maintenance. These studies focused more on maintenance problem solving and the main difficulties are reported along with probable solutions. Another goal of the paper is to analyze the articles by year and type of journal they were published in, to determine the trends in maintenance management studies and recommend future direction for research.
\end{abstract}


Keywords: maintenance management, literature review, conceptual research, empirical research, PMMP

\section{Introduction}

It is only since Second World War that there have been profound advances in engineering and scientific technology that have highlighted the need for more attention to be paid to maintenance of engineering systems. Till very recently, maintenance management was more of a traditional skill based management discipline which depended on experience, guts and luck. Today the question 'Is change in Maintenance Management necessary?' is increasingly being asked. Continual modernization and the pressing need for higher and higher productivity have resulted in the increased development and use of sophisticated \& complex machines and equipments. This has resulted in increased capital employed in production equipment (Waeyenbergh \& Pintelon, 2002). Systems are also becoming more costly relative to their operation $\&$ support. In case of capital equipment used in process and various other plants, which are one-off and cannot be prototype tested, incipient failures occur. This affects production and resulted in loss of revenue. This is further compounded by the fact that in recent years rising inflation has brought with it substantial budgetary constraint in every organization. To control the budget in organizations, downsizing is mostly adopted which reduces the availability of personnel for unscheduled work. Furthermore next to the energy costs, maintenance costs can be the largest part of any operational budget (Hansen, 2006; Lofsten, 2000; Park \& Han, 2001). Hence adequate and timely maintenance actions are required which will minimize the incidence of such failures, and increases the reliability of machines and equipments through the effective management of maintenance function.

Thus it is evident from the preceding discussion that importance of the industrial maintenance is undeniable, and it is now a well established fact that the requirement of maintenance function and therefore the maintenance management has grown tremendously and still growing. Same is case with automobile industries. In recent past automobile industries are under enormous pressure for their survival and growth because of their unique characteristics. With increasing 
automation and mechanization in automobile industries, production processes are becoming highly sensitive to machines and peoples. Consequently, the role of equipment maintenance in automobile industries in controlling quality, quantity; reducing costs and to achieve the high levels of reliability-necessary to meet production targets are more evident and important than ever. To succeed in this new environment, the machines and equipments of an automobile industry must be maintained in ideal operating conditions by effective maintenance.

\subsection{Goals of the research}

It is essential that the present attempt is different from the earlier reviews and more concentrated in coverage, articles were collected and subsequently studied and analyzed for presenting in this work with following objectives

- To consolidate available literature on maintenance management in automobile industries

- To study maintenance management literature and broadly classify it based on some specific criterion

- To analyze and report the most important concept or finding from each study

- To identify evolutionary trends in the field of maintenance management and future prospects

\subsection{Organization of the paper}

The rest of the paper is organized as follows: section 2 provides an introduction and justification for choosing automobile industry for current study. The section 3 describes the classification of available literature according to selected criteria. Thereafter, the paper considers in more detail the contributions and limitations of existing research in maintenance management of auto industries in the form of indepth observations in section 4 and finally ends with conclusion and exhaustive list of research papers reviewed before offering possible avenues for future research in section 5 . 


\section{Industry background}

This paper retrospects the issue of industrial maintenance in automobile industries. The automobile industry has acquired the title of world's largest manufacturing industry (AUTO2009, SOVEREIGN Publications; London). The global boom of the 1980 's was largely because of the automobile revolution. Ford, General Motors and Chrysler, the BIG3 automotive giants of America, had a huge say on the country's economy. They decided the health of the economy and the recent global economic recession has affected them badly. The European automotive industry is currently facing a fight for survival in the face of increasing global competition and a permanent over-supply of the automotive market (May \& Carter, 2001). New vehicles must be launched onto the marketplace with a minimum of delay; it was estimated that an automotive manufacturer in Europe lost US $\$ 1.8$ billion in profit alone (before regaining its market share) by being one year behind its competitors in introducing a new model to the market (Holberton, 1991). This explains the importance of availability of manufacturing equipments. Many developing countries have targeted the automobile sector as a major focus of their industrialization drive (Ito, 2004). They enumerate a number of characteristics to explain why this industry has been considered more conducive to development efforts than other sectors. In 2007, a total of 71.9 million new automobiles were sold worldwide. The markets in North America and Japan were stagnant, while those in South America and other parts of Asia grew strongly. Of the major markets, Russia, Brazil, India and China saw the most rapid growth (http://en.wikipedia.org/wiki/Automotive industry).

The automotive industry crisis of 2008-2009 was a part of a global financial downturn. The crises affected European and Asian automobile manufacturers, but it was primarily felt in the American automobile manufacturing industry. Thus automobile companies around the world are facing intensive competition and therefore are under tremendous pressure to optimize their operations. Among the available areas, where enormous potential exists is industrial maintenance. According to the study conducted by Mobley (1990) reported that from $15 \%$ to $40 \%$ (avg.28\%) of total production cost is attributed to maintenance activities in the factory. Maintenance is a system that operates in parallel to production and can have a great impact on the capacity for production and quality of product produced therefore deserves continuous improvement in industrial environment. Another 
study conducted by Blanchard (1997) states that the estimated cost of maintenance is likely to go even higher in the future with the addition of factory automation. This is mainly true in case of automobile industries due to its specific characteristics viz., big size or large-scale industry, highly labour intensive, large volume of production, highly automated machines and assembly lines, huge capital investment for mass production, a synthetic industry which has wide-ranging related industries and where significant technology transfer affects related industries and a key industry the output of which makes up a significant proportion of gross domestic product (GDP) due to its large scale, when the conditions of market size, infrastructure, and technology levels are satisfied. Considering the importance and interesting slump in automobile industries in the recent times, it is selected for study under the domain of maintenance management.

\section{Method}

This study can be described as theoretical-conceptual, but it is specifically devoted to searching and reviewing the literature on the plant maintenance practices in the automobile industries. Abundance of literature is available in the field of maintenance management from various sources through books and journals but very few specifically concentrate on automobile industries. In this review, publications are analyzed for the purpose of providing insights to the application, growth and development of maintenance concept in automobile industries.

Articles from journals were mainly used because they are published after passing a selection process and are evaluated according to some criteria, as compared with articles from congresses, symposia and websites. Other articles such as exclusive reports in news magazines, newsletters, special columns and editorials are left out as the authors feel that they deal with general information in a limited manner. Similarly books written on maintenance are also omitted from the review. The publications were identified through a number of databases published between 1990 and 2008. It is important to stress from the outset that to identify, locate and acquire publications of interest, the following databases were consulted: Blackwell, Cambridge University Press, Emerald, High-Wire Press, IEEE (Institute of Electrical and Electronic Engineer), Oxford University Press, Pro-Quest, EBSCO and Science Direct Online. To consult the referred journals, the key word 'Maintenance' and 'Automobile' were used to search the articles from the database consulted, the 
terms searched for throughout the entire text and mainly in the title of the article. In the end 55 significant articles in total were collected.

As a part of the research it was decided to classify and analyze the literature in detail. The course of action included the following steps:

- Updating the list to ensure that literature is as current as possible

- For literature search, both hard copy search in established libraries in India and electronic search in World Wide Web were made to ferret out the literature pertaining to industrial maintenance in auto industries. While the authors have tried their best to include as many publications as possible, they do not claim that their listing is complete or exhaustive in nature

- Developing a classification scheme was the next step. First a bibliographical list of all publications was developed and a file was created in Excel spreadsheet

- Keeping these observations in mind the authors decided to approach the review process in a different way, as illustrated in the next part of the paper

\subsection{Classification of literature}

Broadly speaking one may find three main types of Literature Reviews: A general survey of the literature on a particular topic, a focused survey of the literature on a topic and a systematic review (Needham, 2000). In general survey review the reviewer aims to be as comprehensive as possible within certain clear parameters. For example, he or she may choose to restrict themselves to literature published in the English language, or to literature published within the last ten years or to articles published in refereed journals only. Usually the reader judges this kind of review in terms of: Is it analytical or just descriptive? ; Is it up-to-date? Is it relevant to the author's overall study? etc.

In focused survey the reviewer introduces more parameters or restrictions into the selection of the literature to be reviewed. For example, the review may be limited to research which focuses on a particular demographic group or is restricted to research which deploys mass survey techniques or ethnographic approaches, and so on. Systematic review is a term that is most commonly used in medical research 
and increasingly in the review of literature in health care and social work. Systematic reviews are particularly important where the reviewer is reviewing research on the effectiveness of a particular treatment or service. Generally speaking, systematic reviews are usually carried out by highly experienced researchers.

Based on the aforesaid discussion a general review of the literature is attempted in the current work. A wide-ranging classification of the published literature during the period 1990-2008 is presented. A major classification of gathered literature has been carried out as per the year of publications. Figure 1 presents a histogram of number of publications on maintenance in automobile industries for the said period. Following were the observations as per the nos. of publications in the last two decades. A growing and developing literature on this subject was published after 1999. A slump in literature has been observed in the year 2003 and 2005 due to growth in auto industries or may be due to lack of research work. It is observed that around $65 \%$ of the literatures belong to the category of literature published after and in the year 2000 .

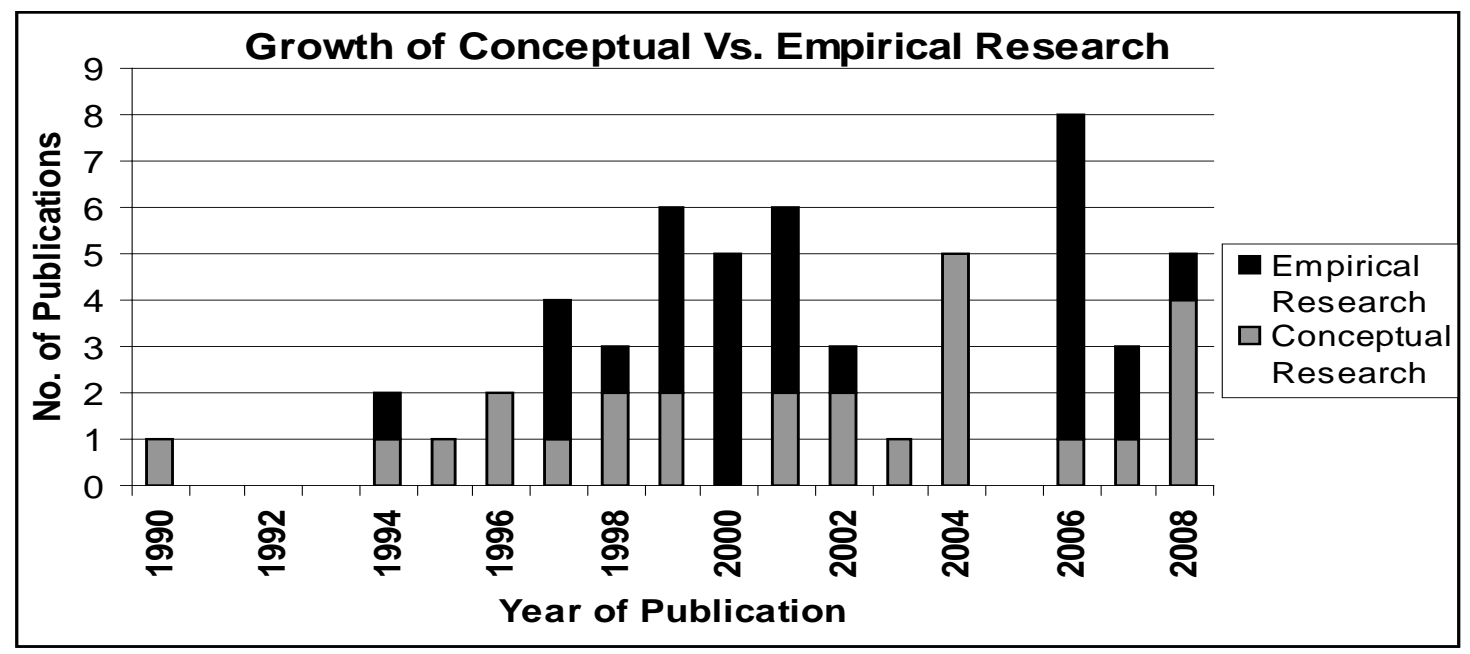

Figure 1. "A combined histogram of no. of published literature on PMMP in Auto industries year wise and their further classification as Conceptual \& Empirical research".

From the definition of general survey it is clear that in general survey review the reviewer aims to be as comprehensive as possible within certain clear parameters. Hence in this review a major classification of collected literature is carried out in two areas based on relevant information presented in the study. The identified 
major areas of maintenance management are 1) Conceptual and 2) Empirical. Articles whose goal was to develop theoretical-concepts work, reviews of the literature, simulations or theoretical modeling were considered to be conceptual. Empirical research included articles that had the goal of undertaking surveys, case studies, research-action or experimental research. It is understandable that a very strict demarcation in the categorization is not possible since there may be certain overlaps in the publications analyzed. An in-depth study of collected literature shows that there are 26 articles belong to conceptual research work while remaining belongs to empirical category out of total 55 articles gathered. Figure 1 also depict the growth of conceptual Vs empirical research work carried out on PMMP in Auto Industries by a histogram on time scale.

A closer analysis of histogram data indicates a trend, which suggests that the contribution to empirical research in the form of case studies and surveys is very irregular and seems to be governed by the condition of automobile industries. During the period of boom there is little contribution and vice-a-versa. The contributions to conceptual research don't seem to follow the same pattern, as it must be. There has been a continuous and sustain pattern of researches made to develop the theoretical concepts. The analysis supports the choice of automobile industry taken for research work. Continuing with classification objective a list of reviewed journals and sources is given along with the no. of articles published in appendix A. Appendix B and C presents the key findings of reviewed publications when classified as conceptual and empirical research respectively chronologically and author wise.

\section{Observations and comments}

Maintenance management is the direction and organization of resources in order to control the availability and performance of industrial plant to some specified level (Gillett, 2001). Maintenance is a function in an organization that operates in parallel with production. Moreover besides being a support function, it has a role in gaining and maintaining competitive advantages. Therefore, it is very important for all relevant stakeholders to be aware of the role of maintenance in achieving sustainable and competitive business environment. An integrated model for maintenance function has been conceptualized and depicted in figure 2 . The primary output of production is the desired product while demand for maintenance 
would be the secondary output as a result of production activities. This output would act as input for the maintenance function. Maintenance results in restored production capacity which would further act as secondary input to production thus completing the maintenance cycle. Thus production manufactures the product while maintenance produces the capacity for production. The quality of the final product is affected by both the production process and the quality of maintenance work.

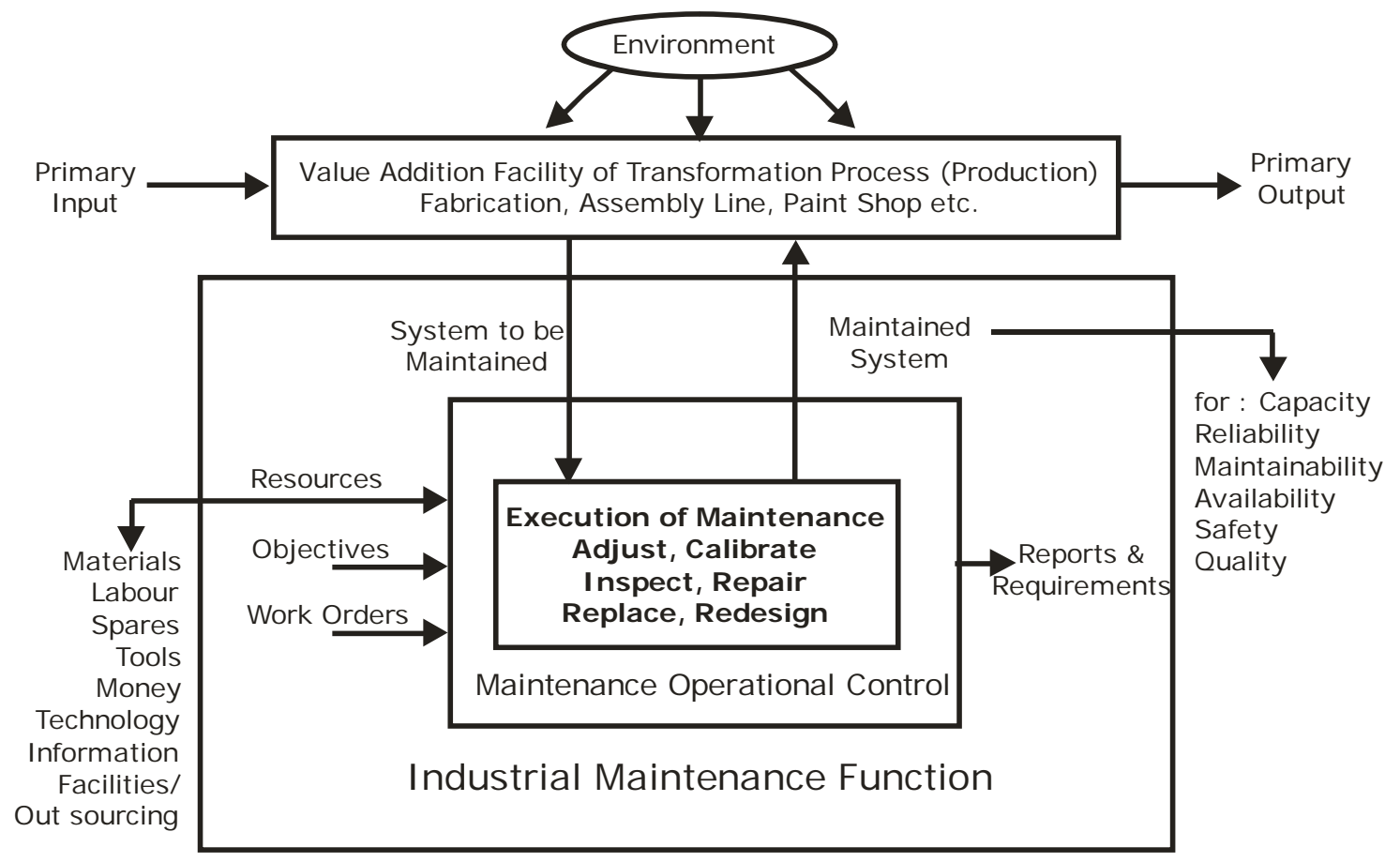

Figure 2. "An integrated input-output model for maintenance function".

Thorsteinsson and Hage (1991) proposed a broad definition of the maintenance task based on viewing the maintenance system as a "Production System" where the "Products" are maintenance services. In this review we have further analyzed the literature on this concept. These authors identify 12 main maintenance tasks or fields that are grouped in to three primary categories viz. The Technical part, The Human Part and The Economic Part (Luxhoj, Riis, \& Thorsteinsson, 1997). Figure 3 shows the definitions of the Thorsteinsson-Hage 12 Maintenance Tasks.

\subsection{The technical part}

The technical category of the maintenance task is comprised of maintenance services and its quality, the methods, resources, materials and control strategies 
required for maintenance. Following were the observation when the literature was analyzed on this aspect.

The technical part:

\section{The 12 main maintenance management fields}

- The maintenance "products". Specification of the different types of services and "products" from the maintenance function. Specification in relation to each plant system.

- Quality of the maintenance "products". Specification of quality of the maintenance jobs. Quality reports, certification documents, decision about maintenance standards, etc.

- Maintenance working methods. Specification of working methods, time standards, relation between maintenance jobs, etc.

- Maintenance resources. Equipment for maintenance, buying maintenance services, information about new equipment, capacity of equipment, usage contro, etc.

- Maintenance materials. Inventory planning (spare parts, etc.), warehousing, relation to vendors, etc.

- Controlling maintenance activities. Scheduling of maintenance jobs, progress in work, manpower planning, etc.

The human part:

- Internal relations in maintenance function. Relation to other departments, corporation and coordination especially to production.

- External relation for the maintenance function. Relation to external parties, especially related to environment and safety. Contact to local authorities, press, labor organization, customer, vendors, neighbors, etc.

- Organization of the maintenance function. Design of the organization, selection of the people, relation between groups of skills, responsibility, and authority.

The economic part:

- $\quad$ Structure of maintenance. Work breakdown of maintenance, responsibility for work packages, area structure, relation to accounting system, specification base (drawings, documentation), etc.

- Maintenance economy. Economic control of maintenance: cost estimates, budgets, cash flow, accounting for the maintenance function. Plant investment and financing.

- Production economy. Production economy versus maintenance economy, cost benefit of maintenance.

Figure 3. "Definitions of the Thorsteinsson-Hage 12 Maintenance Tasks". Source: Luxhoj et al. (1997)

A traditional approach to maintenance in automobile industries has always been to practice preventive maintenance. But predictive maintenance techniques such as vibration analysis are more useful and are being applied to equipments with the expectation of improving equipment reliability and availability while lowering maintenance costs (Chen, 1997; Murry \& Mitchell, 1994; Waeyenbergh, Vannieuwenhuyse, \& Pintelon, 2004). Still today many manufacturing systems are mainly maintained by corrective maintenance combined with a certain amount of scheduled preventive maintenance. So far, little has been done on condition monitoring at the robotic assembly lines (Zeng, 1997). Now a day's Total 
Productivity Maintenance (TPM) is increasingly being applied to improve maintenance function (Bamber, Sharp, \& Hides, 1999; Cigolini \& Turco, 1997; Cooke, 2000). TPM is a contemporary example of various improvement concepts. Although the concept first appeared more than 30 years ago in Japan, it has only recently found it's way to the wider population of companies across Europe, America and Asia, especially within the auto assembly and process industry areas (Andreassen, Gertsen, Christiansen, \& Michelsen, 2004; Labib, 1999; Park \& Han, 2001; Thun, 2008; Turbide, 1995). Further the improvement of maintenance by TPM - can be supported by mobile business in automotive companies (Thun, 2008). Overall Equipment Effectiveness (OEE), as a measure of TPM implementation effectiveness provides an excellent perspective on production improvement but should be balanced by other, more traditional operational measures, there by retaining an overall perspective of the manufacturing environment (Chand \& Shirvani, 2000; Dal, Tugwell, \& Greatbanks, 2000; Ireland $\&$ Dale, 2001; Jonsson \& Lesshammar 1999).

The industry can also be an important factor in equipment maintenance since the type of equipment, customer demands and strategic uncertainty can differ significantly from industry to industry. In the automobile industry, the large automakers have faced much competition in recent years and thus companies such as Toyota, Ford and Saturn are known to have developed programs such as TPM and its adoption (McKone, Schroeder, \& Cua, 1999).

For the effective preventive maintenance, maintenance management information system is the foundation for the data that supports the PM's ability to make effective management decisions. It is important to understand that not all MMISs are the same (Sautter, Jemison, Goes, \& Wooten, 2008). Thus there are different approaches to maintenance management, but despite advances in computer technology and manufacturing techniques, benchmarking studies of actual maintenance performance signal the need for new, improved methods for analyzing and designing maintenance systems (Luxhoj et al., 1997). The application of analytic hierarchy process (AHP) for decision making and to improve the implementation of total productive maintenance is getting momentum in auto industries (Amoedo \& Modarres, 2006; Labib, O'Connor, \& Williams, 1998). 
In present scenario TQM and TQC have become the back bone of industries. It would be imprudent even to think of doing only TQC and skipping TPM, or vice versa (Pramod, Devadasan, Muthu, Jagathyraj, \& Dhakshina Moorthy, 2006; Seth \& Tripathi, 2006). A comparative analysis of the total quality control and total productive maintenance paradigms is available which shows that they can be complementary to each other. Also guidelines for nurturing well-balanced organizations based on potentials of both TQC and TPM in the form of Strategic Staircases model has been proposed (Miyake \& Enkawa, 1999; Parker \& Narayanan, 1996). The implementation of JIT concept in industrial environment is growing day by day. But JIT requires high machine availability while TQC requires that machines are in excellent working condition, which both in turn requires excellent preventive maintenance (Abdallah \& Matsui, 2007; Chen, 1994; Conlon, Devaraj, \& Matta, 2001; McKone, Schroeder, \& Cua, 2001; Sahu, Agnihotri, \& Sadiwala, 2008).

To avoid failure and improve maintenance mathematical models and robust computer aided simulation have been developed to visualize, analyze and optimize complex maintenance problems in an automotive-manufacturing environment. In the modeling a repairable production unit subject to random failures, which supplies input to a subsequent assembly line, operating according to a just-in-time configuration has been considered for analysis. Such a situation is found in many industries especially in automobile manufacturing (Chelbi \& Ait-Kadi, 2004; Sandanayake, Oduoza, \& Proverbs, 2008). Setchi \& White (2003) explained the development environment and stages of creating a Hypermedia Maintenance Manual (HMM) for a manufacturer of automotive equipment. The right policy to counter any mode of failure is that which improves the life cycle profit by reducing the cause of breakdowns in the form of identifying and analyzing different criteria (Labib, 1998).

\subsection{The human part}

The Human category of the maintenance task is comprised of internal relations between the maintenance organization and other departments such as production, external relations to local regulatory authorities, labour organization, vendors and so on, and the design of maintenance organization itself. Human Factor in maintenance management plays an important part for improving efficiency and 
effectiveness (Gillett, 2001; Luxhoj et al., 1997; Turbide, 1995). Productivity improvement by the motor vehicle producers was attained through more efficient utilization of labour ahead of maintenance and other factors (Lieberman, Lau, \& Williams, 1990). In UK and Japan, shop floor employees' of auto industries work in groups within manufacturing cells; improvement teams formed on the basis of production areas and they meet regularly to discuss problems and their proposed solutions. This team culture together with a flat organizational structure has enabled the companies to develop a good information and communication network (Park \& Han, 2001). Further there are four management systems which are important for assurance of assembly quality namely production, quality, maintenance and human resources. It is the human factor which affects the quality of assembly most in a discrete part manufacturing assembly lines of auto industry (Batson \& Wan, 2004).

Currently the $R \& D$ intensity is turning out to be significant in case of automobile industry. Furthermore, there is a significant impact of the $R \& D$ intensity and size of the firm on their productivity. Other factors like energy, labor and maintenance also have an impact on the firm's productivity (Narayanan \& Banerjee, 2006). Thus the evaluation of the maintenance function has identified both weaknesses which have the potential for improvements, and strengths of current maintenance routines. Based on the performance assessment of maintenance department, it is first of all recommended that a brief pre-PM action plan for operators is worked out and implemented to assure its success (Hansen, 2006).

Another concept which is emerging and important in auto industries is the involvement of labour factor in Lean concept. The lean itself is not a single point invention, but the outcome of a dynamic learning process and adapted practices e.g. TPM, JIT etc. (Batson, Hall, \& Hauer, 2001; Cooney, 2002; Holweg, 2007; Kumar, Antony, Singh, Tiwari, \& Perry, 2006). The excellence in equipment maintenance is essential to lean assembly. The Toyota Production System was trapped into the sterile opposition between the empowerment and the management by stress approaches, and has failed to provide a clear understanding of the social and organizational conditions that make this system viable (Pardi, 2007). 


\subsection{The economic part}

The economic category of maintenance task is comprised of the cost structure of maintenance, the economic control of maintenance (Budgets, cash flow etc.) and production economy. Cost effectiveness of maintenance function is thus an important field of management. Cutting edge auto companies are using many new tools to reduce cost effectively. Since reliability can be designed into the equipment by engineering, demonstrated by operations in careful use of the equipment, and it can only be sustained by maintenance. Businesses cannot afford too little reliability because of high failure costs or too much reliability because of high capital costs (Barringer, 1998). Political and other environment rendered the UK an attractive location for Japanese "transplants" cost effectively. Maintenance management is constantly seeking ways to reduce operating costs, optimize the life cycle cost of components, minimize wasted motion and material and increase availability (Chen, 1994; McDermott, 1996). Hence to respond to global challenges, the European car companies had to reduce costs, shed labour, rationalize plants, raise productivity and improve their relationships with suppliers in attempts to boost efficiency (Donnelly, Mellahi, \& Morris, 2002). Proper maintenance helps to keep the life cycle cost down and ensures proper operations and smooth internal logistics. More and more automobile companies are looking for a customized maintenance concept (Waeyenbergh \& Pintelon, 2002).

Maintenance concept is a set of various maintenance interventions (corrective, preventive, condition-based, etc.) and the general structure in which these interventions are brought together. Developing an appropriate maintenance concept is important because of the high direct and indirect costs and because of the operational impact maintenance (Lai, Leung, Tao, \& Wang, 2000; Pintelon, Nagarur, \& Van Puyvelde, 1999; Pintelon, Kumar, \& Vereecke, 2006).

Another concept introduced for reducing cost by many auto industries is agile manufacturing system integrated with maintenance concept. Agile manufacturing systems from an automotive industry maintenance perspective seem to meet the promise of rapid and cost-effective response to manufacturing (Elkins, Huang, \& Alden, 2004). A Latest development in cost reduction effort is the near net shape technology. Cominotti \& Gentili (2008) reported that Near Net Shape technology in automotive industry helps in achieving cost reduction, reduction of process 
variability, quality improvement in the finished product and simplifies maintenance. The partial maintenance productivity goal for a firm is to maximize its maintenance productivity in economic terms and should aim at producing any level of output which is decided upon at minimum maintenance cost with respect to the production systems state. These imputed maintenance costs do not have to be calculated separately, but emerge as a by-product of finding a high productivity index (Lofsten, 2000).

\section{$5 \quad$ Findings and future directions}

A scrutiny of the publications shows that several aspects of maintenance along with many other interesting and diversified applications have been found in sufficient detail. The review exposed some research proposition points which could be: development of appropriate maintenance strategies, JIT in maintenance, maintenance management information system and its implementation, benchmarking in maintenance, application of AHP in maintenance, reliability in maintenance management, application of MCDM in maintenance, maintenance and human factor, maintenance and QFD and most importantly the implementation of TPM.

These insights may serve a great deal towards maintenance function improvement in automobile industries. Thus academicians, practitioners and researchers have a good number of sources in the form of articles, to study, discuss and debate over many aspects of maintenance. In this paper we have argued that despite the burgeoning maintenance management literature, comparatively few studies have shown plant maintenance management practices, delineated metrics, or benchmarking practices in auto industries. Moreover, we propose there has been limited reflection on important insights from the wider contemporary literature on PMMP.

Further Plant Maintenance Management is an important activity in automobile industries, dedicated to translating requirements into activities, to develop new products and services. However, there are several difficulties in its application, among them - interpreting the production needs, defining the correlations between the quality demanded and quality characteristics, difficulty in working in teams, and lack of knowledge about using the method, are major. These difficulties have 
depressed its effective use in making it a competitive advantage. For this reason, it is important to carry out studies to understand PMMP in automobile industries, the purposes for which it has been used, the benefits of its applications and the difficulties in its use in order to seek solution to facilitate its valuable application in the future.

The present review of literature on PMMP, carried out as a part of on-going research, has identified certain issues which have not been satisfactorily addressed. These issues can be regarded as inadequacies and they offer scope for further research and exploration along with other stated problem. The issues identified are as follows:

- Duration of setting new maintenance strategy. Guidelines regarding setting up of a timeframe for conducting new practice are not available. If a method can be described to decide upon the total time involved in implementing new maintenance strategy, it would prove very helpful in setting targets and deadlines.

- Human factors in maintenance activities. Rationale behind formation of cross-functional maintenance teams and responsibility sharing among maintenance teams, have not been discussed in sufficient detail. The role of human factors in maintenance activities needs to be clarified in complete depth to ensure better individual and team working efforts in a new project.

- Cost aspects of maintenance in auto industries. The overall cost incurred in carrying out maintenance function needs to be established, say in terms of cost models or cost equations. This would enable the decision makers to decide upon financial commitment before embarking on the new practices, and to convince the top management. While a precise model is difficult, because of variability of factors involved, an approximate method would be quite useful.

Sometimes, the superior performer as recognized in terms of market leadership or success rate may not be willing to disclose the maintenance practices. This could be a major deterrent in the maintenance process. Further best practices followed in a certain successful organization may not necessarily be the best when adopted by other organizations. Eventually, success rate may also significantly differ across 
organizations. These issues need to be resolved to make maintenance a preferred system in the improvement efforts.

The authors feel that innovative maintenance practices can be applied more judiciously, so a great scope of research is available for new researchers. Success stories reveal that it requires team efforts involving every employee to fully implement the maintenance system. However, awareness among employees regarding different strategies that are involved in maintenance concept, various principles behind these strategies and the use of these strategies in different circumstances plays an important role (Chen, 1997; Gillett, 2001; Labib et al., 1998; McKone et al., 1999; Park \& Han, 2001; Pintelon et al., 1999; Waeyenbergh \& Pintelon, 2002; Zeng, 1997). So these factors are highly important for the success of the maintenance practices in most of the automobile industries.

Nevertheless, despite these contributions, it is important to reflect upon possible limitations of the study. Perhaps the main risk is that the literature review is not exhaustive, since only few already mentioned online repositories were interrogated which were available to authors. Whilst they are widely regarded as an excellent data sources, other databases could have been reviewed for completeness. Furthermore, it is important to acknowledge that our introduction to maintenance management systems focuses mainly on the operations management literature, there is a significant literature in other areas such as strategic management, human resource management and management control systems.

\section{Conclusion}

The paper reviews the research work on plant maintenance management practices in automobile industries under the traditional operation paradigm. The current work gives a broader view of maintenance practices and researches carried across the globe, but as maintenance is now a widely accepted philosophy for competitive advantage, more research work is required in auto industries. Finally, the research needs for future was presented. It is the authors' intention to utilize the knowledge gained from this literature review to develop a comprehensive and holistic design for maintenance methodology that will be presented in the next part of this research. 


\section{Appendices}

\section{A. List of publications referring to the sources}

\begin{tabular}{|c|c|c|}
\hline $\begin{array}{l}\text { Sr. } \\
\text { No. }\end{array}$ & Name of J ournal/ Sources & $\begin{array}{l}\text { No. } \\
\text { Published }\end{array}$ \\
\hline 1 & Computers in Industry & 1 \\
\hline 2 & European Business Review & 1 \\
\hline 3 & European Journal of Operational Research & 2 \\
\hline 4 & Human Factors and Ergonomics in Manufacturing & 1 \\
\hline 5 & ICFAI J ournal of Industrial Economics & 1 \\
\hline 6 & IEEE & 5 \\
\hline 7 & Industrial Management \& Data Systems & 1 \\
\hline 8 & Integrated Manufacturing Systems & 1 \\
\hline 9 & International J ournal Advance Manufacturing Technology & 1 \\
\hline 10 & International J ournal of Operations \& Production Management & 3 \\
\hline 11 & International J ournal of Production Economics & 2 \\
\hline 12 & International J ournal of Quality \& Reliability Management & 2 \\
\hline 13 & International Journal Production Economics & 1 \\
\hline 14 & Journal of Manufacturing Systems & 1 \\
\hline 15 & Journal of Material Processing Technology & 1 \\
\hline 16 & Journal of Operations Management & 3 \\
\hline 17 & J ournal of Quality in Maintenance Engineering & 8 \\
\hline 18 & Management Decision & 1 \\
\hline 19 & Management Science & 2 \\
\hline 20 & New Technology, Work and Employment & 1 \\
\hline 21 & Production and Inventory Management Journal & 1 \\
\hline 22 & Production Planning \& Control & 2 \\
\hline 23 & Quality Progress & 1 \\
\hline 24 & Reliability Engineering and System Safety & 1 \\
\hline 25 & Robotics and Computer-I ntegrated Manufacturing & 2 \\
\hline 26 & Quality Management Journal & 1 \\
\hline 27 & Total Quality Management, & 2 \\
\hline 28 & www. & 6 \\
\hline
\end{tabular}




\section{B. Key findings of conceptual research works on the PMMP in automobile industries}

\begin{tabular}{|c|c|}
\hline $\begin{array}{l}\text { Authors \& year of } \\
\text { publication }\end{array}$ & Key Findings \\
\hline Lieberman et al., 1990 & $\begin{array}{l}\text { Productivity improvement by more efficient utilization of labor } \\
\text { ahead of maintenance. }\end{array}$ \\
\hline Murry et al., 1994 & $\begin{array}{l}\text { Showed the importance of predictive maintenance in effective } \\
\text { maintenance management. }\end{array}$ \\
\hline Turbide, 1995 & $\begin{array}{l}\text { Presented a framework for TPM implementation and stresses the } \\
\text { importance of employee involvement. }\end{array}$ \\
\hline McDermott, 1996 & $\begin{array}{l}\text { Explained how political environment rendered the UK an attractive } \\
\text { location for Japanese "transplants". }\end{array}$ \\
\hline Parker et al.,1996 & $\begin{array}{l}\text { Quality in auto industry can be improved by TPM. It is important to } \\
\text { understand that Japanese methods cannot and should not be } \\
\text { accepted without adapting the culture. }\end{array}$ \\
\hline Luxhoj et al., 1997 & $\begin{array}{l}\text { Benchmarking studies on actual maintenance performance indicate } \\
\text { the need for new, improved methods for analyzing and designing } \\
\text { maintenance systems. }\end{array}$ \\
\hline Labib et al., 1998 & $\begin{array}{l}\text { Analytic Hierarchy Process (AHP) can be used to improve the } \\
\text { implementation of total productive maintenance. }\end{array}$ \\
\hline Barringer, 1998 & $\begin{array}{l}\text { Reliability engineering principles are used in automobile industries } \\
\text { for performance improvement \& cost reduction. }\end{array}$ \\
\hline Labib, 1999 & $\begin{array}{l}\text { Appropriate productive maintenance (APM) is advocated to } \\
\text { addresses the problems with the practical implementation of total } \\
\text { productive maintenance. }\end{array}$ \\
\hline Miyake et al., 1999 & $\begin{array}{l}\text { Guidelines were proposed for nurturing well-balanced organizations, } \\
\text { based on potentials of both TQC and TPM in the form of Strategic } \\
\text { Staircases (SSs) model. }\end{array}$ \\
\hline Batson et al., 2001 & $\begin{array}{l}\text { The excellence in equipment maintenance is essential to lean } \\
\text { assembly. }\end{array}$ \\
\hline Park et al., 2001 & $\begin{array}{l}\text { Explores the impact of TPM on the competitiveness of the auto } \\
\text { company. Long-term benefits of TPM are the result of considerable } \\
\text { investment in HRDM. }\end{array}$ \\
\hline Donnelly et al., 2002 & $\begin{array}{l}\text { European car companies had to reduce costs, shed labour, } \\
\text { rationalize plants, raise productivity and improve maintenance in } \\
\text { attempts to boost efficiency. }\end{array}$ \\
\hline Waeyenbergh et al., 2002 & $\begin{array}{l}\text { A framework is presented for establishing a maintenance concept, } \\
\text { still allowing enough customisation space. }\end{array}$ \\
\hline Setchi et al., 2003 & $\begin{array}{l}\text { Hypermedia maintenance manual (HMM) for a manufacturer of } \\
\text { automotive equipment is developed and presented. }\end{array}$ \\
\hline Elkins et al., 2004 & $\begin{array}{l}\text { Agile manufacturing systems seem to meet the promise of rapid and } \\
\text { cost-effective response to manufacturing, from an automotive } \\
\text { industry perspective. }\end{array}$ \\
\hline Waeyenbergh et al., 2004 & $\begin{array}{l}\text { A multi criterion decision making model (MCDM) can be applied to } \\
\text { tackle the problem of optimization of predictive and preventive } \\
\text { maintenance intervals. }\end{array}$ \\
\hline Andreassen et al., 2004 & $\begin{array}{l}\text { Development of TPM is restricted to an efficient way of conducting } \\
\text { maintenance and the utilization of the conceptual potential will be } \\
\text { limited. }\end{array}$ \\
\hline Batson et al., 2004 & $\begin{array}{l}\text { Quality of assembly is a complex issue and four management } \\
\text { systems are important namely production, quality, maintenance and } \\
\text { human resources. }\end{array}$ \\
\hline Chelbi et al., 2004 & $\begin{array}{l}\text { A repairable production unit subject to random failures, such as in } \\
\text { automobile manufacturing, a mathematical model has been } \\
\text { developed to support maintenance strategy. }\end{array}$ \\
\hline Pe're's et al., 2006 & $\begin{array}{l}\text { Express the problem of supplying the spare parts by the automobile } \\
\text { manufacturers. Thus the need of effective maintenance system } \\
\text { further increases. }\end{array}$ \\
\hline
\end{tabular}




\begin{tabular}{|l|l|}
\hline Holweg, 2007 & $\begin{array}{l}\text { Lean concept itself is not a single point invention, but the outcome } \\
\text { of a dynamic learning processes e.g. TPM, JIT etc. emanating from } \\
\text { the automotive and textile sectors. }\end{array}$ \\
\hline Cominotti et al., 2008 & $\begin{array}{l}\text { Near net shape technology in automotive industry helps in achieving } \\
\text { cost reduction and simplifies maintenance. }\end{array}$ \\
\hline Sautter et al., 2008 & $\begin{array}{l}\text { The maintenance management information systems are the } \\
\text { foundation for the data that supports the PM's ability to make } \\
\text { effective management decisions. }\end{array}$ \\
\hline Thun, 2008 & $\begin{array}{l}\text { How mobile devices can be used to improve TPM in automotive } \\
\text { companies in order to increase the OEE. }\end{array}$ \\
\hline Sandanayake et al., 2008 & $\begin{array}{l}\text { The outcome of the study was a robust mathematical model that } \\
\text { highlights the significance of JIT drivers such as TPM in the } \\
\text { manually operated mixed-model auto assembly lines. }\end{array}$ \\
\hline
\end{tabular}




\section{Key findings of empirical research works on the PMMP in automobile industries}

\begin{tabular}{|c|c|}
\hline $\begin{array}{l}\text { Authors \& year of } \\
\text { publication }\end{array}$ & Key Findings \\
\hline Chen, 1994 & $\begin{array}{l}\text { In the Japanese philosophy of just-in-time }(\mathrm{JIT}) \text { and total quality } \\
\text { control (TQC), excellent preventive maintenance is a critical } \\
\text { ingredient.. }\end{array}$ \\
\hline Zeng, 1997 & $\begin{array}{l}\text { Maintenance function is shifting from failure-based CM to user- } \\
\text { based scheduled preventive maintenance, and finally to a predictive } \\
\text { JIT condition-based maintenance. }\end{array}$ \\
\hline Chen, 1997 & $\begin{array}{l}\text { Preventive Maintenance management is an excellent measure of } \\
\text { management excellence and it requires a long term commitment } \\
\text { and continuous monitoring. }\end{array}$ \\
\hline Cigolini et al., 1997 & $\begin{array}{l}\text { There exist three basic models for developing TPM program, namely } \\
\text { Kaizen oriented model, Plant oriented model and Shop-floor } \\
\text { oriented model. }\end{array}$ \\
\hline Labib, 1998 & $\begin{array}{l}\text { Developing a maintenance programme is an iterative process that } \\
\text { involves different decision makers, who may have conflicting } \\
\text { objectives. }\end{array}$ \\
\hline McKone et al., 1999 & $\begin{array}{l}\text { While environmental contextual factors, such as country, help to } \\
\text { explain differences in TPM implementation, managerial CF, are more } \\
\text { important to the execution of TPM. }\end{array}$ \\
\hline Pintelon et al., 1999 & $\begin{array}{l}\text { Developing an appropriate maintenance concept is important } \\
\text { because of the high direct and indirect costs but it is difficult, } \\
\text { especially with complex, highly automated technology or for new } \\
\text { equipment for which not many data are available. }\end{array}$ \\
\hline Bamber et al., 1999 & $\begin{array}{l}\text { The automotive industries are leaders in the UK for adoption of } \\
\text { techniques such as WCM, TQM, TPM etc., and TQM requires both } \\
\text { effective and efficient plant maintenance. }\end{array}$ \\
\hline Jonsson et al., 1999 & $\begin{array}{l}\text { Presented a case study from the manufactures of large construction } \\
\text { vehicles in Sweden which identifies six requirements: four critical } \\
\text { dimensions (what to measure) and two characteristics (how to } \\
\text { measure) of an OMP system. }\end{array}$ \\
\hline Chand et al., 2000 & $\begin{array}{l}\text { Despite time and money spent on the development of the advanced } \\
\text { plant and its equipment, there has not been enough attention paid } \\
\text { to define comprehensive maintenance strategies, practices and } \\
\text { policies. }\end{array}$ \\
\hline Cooke, 2000 & $\begin{array}{l}\text { Implementing TPM is by no means an easy task, which is heavily } \\
\text { burdened by political, financial, departmental and inter-occupational } \\
\text { barriers. }\end{array}$ \\
\hline Lai et al., 2000 & $\begin{array}{l}\text { The sequential method can be used to solve a maintenance and } \\
\text { replacement problem efficiently and thus effectiveness of Preventive } \\
\text { Maintenance can be realized. }\end{array}$ \\
\hline Lofsten, 2000 & $\begin{array}{l}\text { Described and presented partial maintenance productivity goal and } \\
\text { model for a firm based on the empirical study. Productivity and } \\
\text { efficiency calculations are made for two purposes, to decide upon } \\
\text { the allocation of resources and to evaluate the performance of a } \\
\text { business. }\end{array}$ \\
\hline Dal et al., 2000 & $\begin{array}{l}\text { OEE is best suited for environments of high volume based } \\
\text { manufacturing where capacity utilization is of a high priority and } \\
\text { stoppages are expensive in terms of lost capacity. }\end{array}$ \\
\hline Conlon et al., 2001 & $\begin{array}{l}\text { Initial vehicle quality is related to the amount of routine } \\
\text { maintenance performed by consumers on their vehicles and the } \\
\text { consumers who perceive they own better quality vehicles tend to } \\
\text { take better care of them. }\end{array}$ \\
\hline McKone et al., 2001 & $\begin{array}{l}\text { Practitioners should pay closer attention to their maintenance } \\
\text { management practices and TPM can be a strong contributor to the } \\
\text { strength of the organization and has the ability to improve } \\
\text { Manufacturing Performance. }\end{array}$ \\
\hline
\end{tabular}




\begin{tabular}{|c|c|}
\hline I reland et al., 2001 & $\begin{array}{l}\text { Focuses a study of TPM implementation in three UK companies } \\
\text { because of the business difficulties which brought with them the } \\
\text { stability for factory. }\end{array}$ \\
\hline Gillett, 2001 & $\begin{array}{l}\text { Human factors play a major part in the running of a dynamic } \\
\text { organisation. A 'pre-determined' list of factors does not exist, and } \\
\text { each individual department will certainly have its own. }\end{array}$ \\
\hline Cooney, 2002 & $\begin{array}{l}\text { Tested the claim made about the universality of lean production and } \\
\text { concluded that it provides only a partial model of manufacturing } \\
\text { system, if it can not account for the range of circumstances faced } \\
\text { by companies like maintenance, market economy etc. }\end{array}$ \\
\hline Seth et al., 2006 & $\begin{array}{l}\text { TQM and TPM are effective tools in improving business performance } \\
\text { of I ndian manufacturing industry, both in terms of profitability and } \\
\text { operational parameters. }\end{array}$ \\
\hline Pintelon et al., 2006 & $\begin{array}{l}\text { A framework is presented using Hayes and Wheelwright's four-stage } \\
\text { framework to identify and evaluate the effectiveness of a given } \\
\text { maintenance strategy in a company. }\end{array}$ \\
\hline Pramod et al., 2006 & $\begin{array}{l}\text { Various TQM strategies have been infused in TPM principles and one } \\
\text { such strategy is QFD. Yet the world has not nourished with the } \\
\text { synergic power of integrating them. }\end{array}$ \\
\hline Amoedo et al., 2006 & $\begin{array}{l}\text { Preferred metrics to monitor Maintenance Operations under a } \\
\text { complex socio-economical environment were determined and the } \\
\text { methodology resulted in a small set of metrics to monitor and } \\
\text { effectively manage maintenance operations. }\end{array}$ \\
\hline Narayanan et al., 2006 & $\begin{array}{l}\text { There is a significant impact of the R\&D intensity and size of the } \\
\text { firm on their productivity, along with other factors like energy, labor } \\
\text { and maintenance. }\end{array}$ \\
\hline Kumar et al., 2006 & $\begin{array}{l}\text { The study successfully proposes a Lean Sigma framework to reduce } \\
\text { the defect occurring in the final product (automobile accessories) } \\
\text { manufactured by a die-casting unit. }\end{array}$ \\
\hline Hansen, 2006 & $\begin{array}{l}\text { The study is directed to the performance assessment of } \\
\text { maintenance department and designing of a feedback system for } \\
\text { providing data on planned and unplanned maintenance work. }\end{array}$ \\
\hline Pardi, 2007 & $\begin{array}{l}\text { The TPS becomes a much less efficient system on the long run } \\
\text { without a stable relationship between the actors of the shop floor as } \\
\text { it exerts a constant pressure on the workers and on the team by } \\
\text { forcing on them contradictory priorities. }\end{array}$ \\
\hline Abdallah et al., 2007 & $\begin{array}{l}\text { TPM should be considered as one of the main pillars for plants } \\
\text { implementing JIT production to improve the performance, as JIT } \\
\text { production alone cannot yield superior performance results. }\end{array}$ \\
\hline Sahu et al., 2008 & $\begin{array}{l}\text { Indian repair workshops are gearing up to respond fast to the } \\
\text { growing awareness for high quality and implementation of TQM is a } \\
\text { must for organisation's survival and growth. }\end{array}$ \\
\hline
\end{tabular}

\section{Acknowledgments}

The authors wish to thank all those who provided generous support and advice in assisting and collecting the research papers from various sources. They also extend their gratitude to anonymous reviewers and editor of this journal for their constructive comments that enabled us to improve the quality of this paper.

\section{References}

Abdallah, A. B., \& Matsui, Y. (2007). JIT and TPM: Their relationship and impact on JIT and Competitive Performances. Retrieved 01/09/2009, from http://as.nida.ac.th/resource/asconf_resource/apdsi2007/papers/Final_129.pdf 
Amoedo, M. M., \& Modarres, M. (2006). A Structured Methodology for Identifying Performance Metrics and Monitoring Maintenance Effectiveness. RAMS '06, Annual Reliability and Maintainability Symposium, IEEE, 239-246.

Andreassen, M., Gertsen, F., Christiansen, T., \& Michelsen, A. U. (2004). Status and trends in the development of Total Productive Maintenance (TPM) - a review of international articles. Conference paper published in proceedings from $\mathrm{ClNet}$ 2004, Sydney, ISBN 1-74108-069-X.

Bamber, C. J., Sharp, J. M., \& Hides, M. T. (1999). Factors affecting successful implementation of total productive maintenance: A UK manufacturing case study perspective. Journal of Quality in Maintenance Engineering, 5(3), 162-181. doi: $10.1108 / 13552519910282601$

Barringer, H. P. (1998). How to Use Reliability Engineering Principles for Business Issues. Reliability Symposium, La Platta, Argentina, p.22. Retrieved 01/09/2008, from $\quad$ http://www.barringer1.com/pdf/How-To-Use-Reliability-EngineeringPrinciples-For-Business-Issues.pdf

Batson, R., Hall, D., \& Hauer, D. (2001). The Role of Equipment Maintenance in Lean Assembly Systems. Proceedings of the Maintenance and Reliability Conferences (MARCON 2001), May 6-9.

Batson, R. G., \& Wan Q. (2004). How Is Quality of Assembly Assured? The Quality Management J ournal, 11(3), 61-68.

Blanchard, B.S. (1997). An enhanced approach for implementing TPM in the manufacturing environment. Journal of Quality in Maintenance Engineering, 3(2), 69-80.

doi: $10.1108 / 13552519710167692$

Chand, G., \& Shirvani, B. (2000). Implementation of TPM in cellular manufacture. J ournal of Material Processing Technology, 103, 149-154. doi: 10.1016/S0924-0136(00)00407-6

Chelbi, A., \& Ait-Kadi, D. (2004). Analysis of a production/inventory system with randomly failing production unit submitted to regular preventive maintenance. 
European J ournal of Operational Research, 156, 712-718.

doi: 10.1016/S0377-2217(03)00254-6

Chen, F. (1994). Benchmarking: Preventive Maintenance Practices at Japanese Transplants. International J ournal of Quality \& Reliability Management, 11(8), 1926.

\section{doi: $10.1108 / 02656719410070084$}

Chen, F. (1997). Issues in the continuous improvement process for preventive maintenance: Observations from Honda, Nippondenso and Toyota. Production and Inventory Management J ournal, 38(4), Fourth Quarter, 13-16.

Cigolini, R., \& Turco, F. (1997). Total productive maintenance practices: a survey in Italy. J ournal of Quality in Maintenance Engineering, 3(4), 259-272.

doi: 10.1108/13552519710176872

Cominotti, R., \& Gentili, E. (2008). Near net shape technology: An innovative opportunity for the automotive industry. Robotics and Computer-Integrated Manufacturing, 24, 722-727.

doi: 10.1016/j.rcim.2008.03.009

Conlon, E., Devaraj, S., \& Matta, K. F. (2001). The Relationship between Initial Quality Perceptions and Maintenance Behavior: The Case of the Automotive Industry. Management Science, 47(9), 1191-1202.

doi: $10.1287 / \mathrm{mnsc}$ 47.9.1191.9788

Cooke, F. L. (2000). Implementing TPM in plant maintenance: some organizational barriers. International J ournal of Quality \& Reliability Management, 17(9), 100316.

\section{doi: $10.1108 / 02656710010378789$}

Cooney, R. (2002). Is "lean" a universal production system? Batch production in the automotive industry. International Journal of Operations \& Production Management, 22(10), 1130-1147.

doi: $10.1108 / 01443570210446342$

Dal, B., Tugwell, P., \& Greatbanks, R. (2000). Overall equipment effectiveness as a measure of operational improvement: A practical analysis. International J ournal of 
Operations and Production Management, 20(12), 1488-1502.

doi: $10.1108 / 01443570010355750$

Donnelly, T., Mellahi, K., \& Morris D. (2002). The European Automobile Industry: escape from parochialism. European Business Review, 14(1), 30-39. doi: $10.1108 / 09555340210414223$

Elkins, D. A., Huang, N., \& Alden, J. M. (2004). Agile manufacturing systems in the automotive industry. International J ournal Production Economics, 91, 201-214. doi: 10.1016/i.ijpe.2003.07.006

Gillett, K. (2001). Measuring maintenance performance: A structured approach. Elmina Associates limited. Retrieved 30/08/2009, from http://www.elmina.net/download_library/Measuring_Maintenance Performance.pdf

Hansen, I. H. (2006). Performance Measurement of the Maintenance Function within Ecomold Ltd. Master thesis in Industrial Economy and Information Management, Agder University College, Grimstad, p1-69. Retrieved 01/09/2009, from

http://student.grm. hia.no/master/ind06/ind590/g08/Masterl ND\% C3\%98K06_Iva r_Homme_Hansen.pdf

Holberton, S. (1991). Let's do this in Stages, Financial Times, London, p.8.

Holweg, M. (2007). The genealogy of lean production. Journal of Operations Management, 25, 420-437.

doi: 10.1016/j.jom.2006.04.001

Ireland, F., \& Dale, B. G. (2001). A study of total productive maintenance implementation. Journal of Quality in Maintenance Engineering, 7(3), 183-191. doi: $10.1108 / 13552510110404495$

Ito, K. (2004). Foreign ownership and plant productivity in the Thai automobile industry in 1996 and 1998: a conditional quantile analysis. Journal of Asian Economics, 15, 321-353.

doi: 10.1016/j.asieco.2004.02.005 
Jonsson, P., \& Lesshammar, M. (1999). Evaluation and improvement of manufacturing performance measurement systems - the role of OEE. International J ournal of Operations and Production Management, 19(1), 55-78. doi: $10.1108 / 01443579910244223$

Kumar, M., Antony, J., Singh, R. K., Tiwari, M. K., \& Perry, D. (2006). Implementing the Lean Sigma framework in an Indian SME: a case study. Production Planning \& Control, 17(4), 407-423.

doi: $10.1080 / 09537280500483350$

Labib, A.W. (1998). World-class maintenance using a computerized maintenance management system. J ournal of Quality in Maintenance Engineering, 4(1), 66-75. doi: $10.1108 / 13552519810207470$

Labib, A.W., O'Connor, R.F., \& Williams, G.B. (1998). An effective maintenance system using the analytic hierarchy process. Integrated Manufacturing Systems, 9(2), 87-98.

\section{doi: $10.1108 / 09576069810202005$}

Labib, A. W. (1999). A frame work for benchmarking appropriate productive maintenance. Management Decision, 37(10), 792-799.

doi: $10.1108 / 00251749910302890$

Lai, K. K., Leung, F. K. N., Tao, B., \& Wang, S. Y. (2000). Practices of preventive maintenance and replacement for engines: A case study. European Journal of Operational Research, 124, 294-306.

doi: 10.1016/S0377-2217(99)00382-3

Lieberman, M. B., Lau, L. J., \& Williams, M. D. (1990). Firm-level Productivity and Management Influence: a comparison of U.S. and Japanese Automobile Producers. Management Science, 36(10), 1193-1215.

doi: $10.1287 / \mathrm{mnsc}$. 36.10 .1193

Lofsten, H. (2000). Measuring maintenance performance-in search for a maintenance productivity index. International Journal of Production Economics, 63, 47-58.

doi: 10.1016/S0925-5273(98)00245-X 
Luxhoj, J. T., Riis, J. O., \& Thorsteinsson, U. (1997). Trends and perspectives in industrial maintenance management. Journal of Manufacturing Systems, 16(6), 437-453.

\section{doi: $10.1016 / 50278-6125(97) 81701-3$}

May, A., \& Carter, C. (2001). A case study of virtual team working in the European automotive industry. International J ournal of Industrial Ergonomics, 27, 171-186. doi: 10.1016/S0169-8141(00)00048-2

McKone, K. E., Schroeder, R. G., \& Cua, K. O. (1999). Total productive maintenance: a contextual view. Journal of Operations Management, 17(2), 123144.

\section{doi: $10.1016 / 50272-6963(98) 00039-4$}

McKone, K. E., Schroeder, R. G., \& Cua, K. O. (2001). The impact of total productive maintenance practices on manufacturing performance. Journal of Operations Management, 19(1), 39-58.

doi: $10.1016 / 50272-6963(00) 00030-9$

McDermott M. C. (1996). The revitalization of the UK automobile industry. Industrial Management \& Data Systems, 96(5), 6-10.

doi: $10.1108 / 02635579610123280$

Miyake, D. I., \& Enkawa, T. (1999). Matching the promotion of total quality control and total productive maintenance: An emerging pattern for the nurturing of wellbalanced manufacturers. Total Quality Management, 10(2), 243- 269.

Mobley, R.K. (1990). An Introduction to Predictive Maintenance. Van Nostrand Reinhold, New York.

Murry, R. J., \& Mitchell, B. F. (1994). Cost Savings from a Practical PredictiveMaintenance Program. Proceedings Annual Reliability and Maintainability Symposium, IEEE, 206-209.

Narayanan, K., \& Banerjee, S. (2006). R\&D and Productivity in Select Indian Industries. ICFAI J ournal of Industrial Economics, 7-19. 
Needham, G. (2000). Research and Practice: making a difference, Part 2, Chapter 7, in R. Gomm and C. Davies, Using Evidence in Health and Social Care, Sage Publications, London, 137-138.

Pardi, T. (2007). Redefining the Toyota Production System: the European side of the story". New Technology, Work and Employment, ISSN 0268-1072, Journal compilation, Blackwell Publishing Ltd., 2-20.

Park, K. S., \& Han, S. W. (2001). TPM-Total Productive Maintenance: Impact on Competitiveness and a Framework for Successful Implementation. Human Factors and Ergonomics in Manufacturing, 11(4), 321-338.

doi: $10.1002 / \mathrm{hfm} .1017$

Parker, E., \& Narayanan, M. (1996). Quality Control. Southcon/96, Conference Record, IEEE, 556-560.

Pe're`s, F., \& Noyes, D. (2006). Envisioning e-logistics developments: Making spare parts in situ and on demand: State of the art and guidelines for future developments. Computers in Industry, 57, 490-503.

Pintelon, L., Nagarur, N., \& Van Puyvelde, F. (1999). Case study: RCM - yes, no or maybe? J ournal of Quality in Maintenance Engineering, 5(3), 182-191.

doi: $10.1108 / 13552519910282638$

Pintelon, L., Kumar, P.S., \& Vereecke, A. (2006). Evaluating the effectiveness of maintenance strategies. Journal of Quality in Maintenance Engineering, 12(1), 720.

doi: $10.1108 / 13552510610654501$

Pramod, V. R., Devadasan, S. R., Muthu, S., Jagathyraj, V. P., \& Dhakshina Moorthy, G. (2006). Integrating TPM and QFD for improving quality in maintenance engineering. Journal of Quality in Maintenance Engineering, 12(2), 150-171.

doi: $10.1108 / 13552510610667174$

Sahu, V. K., Agnihotri, G., \& Sadiwala, C. M. (2008). An Empirical Study on Total Quality Management in Maintenance and Repair Workshops in India. Proceedings of the IEEE- IEEM, 1557-1561. 
Sandanayake, Y. G., Oduoza, C. F., \& Proverbs, D. G. (2008). A systematic modelling and simulation approach for JIT performance Optimization. Robotics and Computer-Integrated Manufacturing, 24, 735-743.

doi: 10.1016/j.rcim.2008.03.013

Sautter, F. C., Jemison, P. W., Goes, C. M., \& Wooten, J. M. (2008). An Integrated Maintenance Management Information System is the Key to Enabling Condition Based Maintenance. 2008 Annual Reliability and Maintainability Symposium, IEEE, 508-513.

Setchi, R., \& White, D. (2003). The development of a hypermedia maintenance manual for an advanced manufacturing company. International Journal Advance Manufacturing Technology, 22, 456-464.

doi: $10.1007 / \mathrm{s} 00170-002-1513-x$

Seth, D., \& Tripathi, D. (2006). A Critical Study of TQM and TPM Approaches on Business Performance of Indian Manufacturing Industry. Total Quality Management, 17(7), 811-824.

Thorsteinsson U., \& Hage C. (1991). Maintenance Management Profiles for Industrial Systems. Operational Reliability and Systematic Maintenance, Elsevier Applied Science, 283-303.

Thun, J.H. (2008). Supporting total productive maintenance by mobile devices. Production Planning \& Control, 19(4), 430-434.

doi: $10.1080 / 09537280802034588$

Turbide, D. A. (1995). Japan's new advantage: Total productive maintenance. Quality Progress, 28(3), 121-123.

Waeyenbergh, G., \& Pintelon, L. (2002). A framework for maintenance concept development. International J ournal of Production Economics, 77, 299-313. doi: 10.1016/S0925-5273(01)00156-6

Waeyenbergh, G., Vannieuwenhuyse, B., \& Pintelon L. (2004). A model to determine the cleanliness measurement interval in an automotive paint shop. Journal of Quality in Maintenance Engineering, 10(1), 37-46.

doi: $10.1108 / 13552510410526857$ 
Zeng, S.W. (1997). Discussion on maintenance strategy policy and corresponding maintenance system in manufacturing. Reliability Engineering and System Safety, 55, 151-162.

doi: 10.1016/S0951-8320(96)00004-X

Journal of Industrial Engineering and Management, 2010 (www.jiem.org)

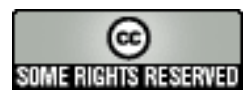

Article's contents are provided on a Attribution-Non Commercial 3.0 Creative commons license. Readers are allowed to copy, distribute and communicate article's contents, provided the author's and Journal of Industrial Engineering and Management's names are included. It must not be used for commercial purposes. To see the complete license contents, please visit http://creativecommons.org/licenses/by-nc/3.0/. 